\title{
Slope stability monitoring in open pit mines using 3D terrestrial laser scanning
}

\author{
Miroslawa Bazarnik $^{*}$ \\ Cracow University of Technology, Civil Engineering Department, Cracow, Poland
}

\begin{abstract}
In open pit mines the aspect of preventing and forecasting the threat of landslides and rock falls is crucial issue because of the significant consequences that instabilities may have. Systematic slope stability monitoring is necessary to ensure safe and continuous mining operations. The development of innovative technologies, such as 3D laser scanning, opens up new possibilities, especially in the case of large and hard-to-reach areas, such as open pit mines. Terrestrial laser scanners (TLS) provide fast, efficient, detailed, and accurate three-dimensional data. The article discusses the use of $3 \mathrm{D}$ terrestrial laser scanning method to monitor slope displacements and landslides in open pit mines. The first part of the article discusses the risk scale of gravitational displacement on the slopes, on examples of Polish open pit mines, and introduces the most common slope monitoring methods. Then, the principles of 3D terrestrial laser scanning were defined, and some examples of TLS applications in the open pit mines were presented.
\end{abstract}

Keywords: open pit mines, terrestrial laser scanner, displacement monitoring, landslide

\section{Introduction}

The mining of mineral raw materials using the opencast method is accompanied by a number of natural hazards, among which mass movements, that is the movement of rock masses due to the gravity, deserve special attention. Gravitational deformations of the rock mass are landslides and rock falls, sometimes covering the area beyond the upper edge of the excavation. During the mine exploitation period, numerous landslides of various sizes are usually recorded on the open-pit slopes. The volume of displaced earth masses for the largest landslides in the open pits reaches 6-8 million $\mathrm{m}^{3}$, but most often they amount to several dozen to several hundred thousand $\mathrm{m}^{3}$ [1]. The stability loss of excavations or dumping ground slopes, as a result of mining operations and natural geological processes taking place, can lead to serious changes in the rock mass causing landslides, thus posing a threat to the health and life of the mine crew. Such hazards occur on a large scale in brown coal mines, but they can also occur at exploitation of ceramic and rock raw material deposits, especially in karstic areas.

The issue of geodetic and geotechnical monitoring is of key importance in the aspect of preventing and forecasting the threat of landslides and rock outcrops. Monitoring is an 
important element of threat management, which includes both the identification of threats as well as their assessment and characteristics (supported by geographic information systems and related databases, including historical information). The threat extent depends on the geological structure of the deposit, including variability of the geotechnical and hydrogeological conditions. Moreover, it depends on the area and size of the excavation, character of the exploitation systems, as well as the machinery and equipment used. The development of innovative technologies, such as 3D laser scanning, opens up new possibilities, especially in the case of large and hard-to-reach areas, such as open pit mines. Terrestrial laser scanners (TLS) provide fast and efficient, detailed and highly accurate threedimensional data. TLS cover a wide range of applications, including topographic mapping, as-built and architectural studies, and monitoring of engineering structures.

This article presents the use of 3D laser scanning technology in the mining industry. It is a review of existing solutions, aimed to discuss the use of the laser scanner to monitor the movement of slopes and landslides in open pit mines. In the case of slopes already unstable, monitoring is often the only chance to predict the degree of threat and direction of the mass movement development. 3D scanning methods can complement traditional geodetic methods.

\section{The risk scale of the slope movement occurrence in Polish open pit mines}

Open pit mining is an important element of Polish economy, providing raw materials for, among others, energy, road and construction industries, and gaining more and more interest among capital managers, both domestic and foreign. As a result of mining exploitation, the rock mass balance is disturbed, which may lead to risks for the mine and the adjacent environment. In case of violation of the natural equilibrium, geological and engineering changes may take place, resulting in loss of stability and, as a consequence, deformation of the rock masses [2].

The basic geotechnical threats include sliding ground masses and formation of rocky outcrops on permanent and operational slopes of outcrops and dumps, which may threaten people, machines, objects and the continuity of mining operations. Prevention of negative effects of phenomena occurring in the rock mass is based on detailed recognition of the geological structure and mechanical properties of rocks and soils, as well as continuous monitoring of the processes in due course. Moreover, the landslide hazard may be reduced by analysis of geological and engineering conditions and identification of threatened areas within individual mining facilities. The scale of threat of landslide movements is reflected in a number of examples of landslides quoted below, which took place in lignite mines, affecting the continuity and safety of mining operations. They include landslides, which occurred in the "Turów" Coal Mine, deformations on the western steep slope in the area of the Nysa River Pillar threatening the pillar's stability and the interruption of the Nysa riverbed in July 1989 [4]. In the years 1993 - 2007, only four landslides were detected on the northern slope of the "Turów" Coal Mine [5]. In 1994, on the slope of the external dump, the landslide was the largest in terms of the number of displaced masses, although not the most dangerous in terms of the potential impact on the mine [6]. In September 2016, the landslide encompassed the area of 6 square kilometers [7] on the internal dump, caused gigantic material losses, stopping coal mining and sale to individual recipients, as well as limiting the work capacity of the Turów Power Plant (Fig. 1). Some devices, including belt conveyors, have been destroyed. The spoil was also covered.

In the Brown Coal Mine "Bełchatów" since the beginning of earthworks, the formation of landslides was recorded on permanent and working slopes, with varying severity and of various sizes, often affecting mining works, drainage of the excavation, or power supply of 
the mine with electricity. Landslides which formed on the steep south and north slopes, each time affected the mining activity. In 2005, volume of landslide masses displaced on the southern slope was estimated for approx. 3.5 million $\mathrm{m}^{3}[2,6]$.

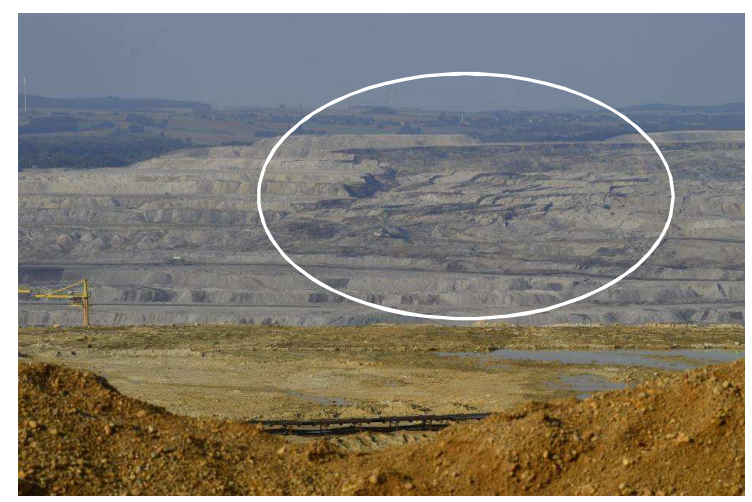

Fig. 1. Landslide in the open pit mine "Turów" - 2016 [3].

In 1996 in the Brown Coal Mine "Konin"the cut of organic land on the foreland of the "Jóźwin" and "Kazimierz Północ" open pits resulted in a rapid fall of the cold masses to the working level $[2,8]$. Displaced grounds covered the working level with a layer of up to 3-4 $\mathrm{m}$, immobilizing the mechanical equipment. In 2002 in the Brown Coal Mines "Konin" and "Adamów" landslides were caused by insufficient discharge of residual waters as well $[2,8]$. Examples of landslides that posed a threat to the plant's operations and general safety could be found not only in brown coal mines, e.g. in 1999 in the "JARO" SA coal mine, in the "Stanisław" excavation, a landslide developed in the area immediately adjacent to the protective pillar established for the buildings of the village of Rusko, which forced evacuation of the population from the nearest buildings [2].

In 2004, two landslides were noted at the Diabase Mine "Niedźwiedzia Góra", on the northern slope and on the southern part of the eastern slope, which caused partial destruction and backfilling of technological roads, destruction of the pipeline and damage to LV and MV power lines [2]. In 2004, a landslide took place in the Basalt Mine "Gracze" on the western slope [2]. In rock salt mines, the threat posed by peeling rocks from solid and working exploitation walls is common. This threat is related to the formation of rock overhangs, cracks and fissures as a result of the blasting technique applief for the deposit exploitation. Formation of landslide hazard is also influenced by the geological structure, i.e. deposit retention, tectonics, karst phenomena and directions of exploitation applieed in mining plants [8].

Exploitation of brown coal deposits requires transfer and storage of earth and rock mass on the dumping ground. The most frequently occurring processes that may arise at formation of external and internal dump are landslides on boulder slopes as well as runoff and sludge scarp escaping. The process of displacement of the soil surface can also occur in front of the face of the dumping ground. Experience and practice acquired in the exploitation of lignite, in particular in the Brown Coal Mines: "Bełchatów" and "Turów", allow for more and more precise analysis of the state of geotechnical threats, including these due to natural conditions as well [2,8].

The most common factors affecting the formation and development of landslides include: inclination of rock layers, tectonics and geomechanical properties of rocks, such as cohesion, internal friction angle and pore pressure. Both exploitation pits and dumps are designed in such a way as to meet the geotechnical safety requirements of slopes, and thus the safety of operation and impact on nearby infrastructure. As a result of mine operations, terrain deformations may occur. Both continuous and discontinuous deformations can potentially 
affect housing developments within the limits of their impact. There may be discontinuous deformations, in the form of slopes, and deformations of the terrain surface. It is also possible that continuous deformations occur due to subsidence of the terrain surface brought about by dehydration of the rock mass. The risk of slope deformation can be diagnosed through comprehensive reconnaissance and multidirectional monitoring and appropriate mining and technological activities.

\section{Slope monitoring methods}

The fundamentals of effective monitoring consist in geological recognition and execution of precise geodetic and geotechnical measurements, as well as possibilities of fast data entry and processing, which the basis for undertaking the necessary preventive actions, and the actions aimed at eventual liquidation of the effects which did occur.

The selection of measurement methods used to determine the displacement of building objects depends on three basic factors [9]:

- rate of changes occurring on the tested object,

- type of determined displacements :

- horizontal (two components in the horizontal plane and time),

- vertical (one component in the vertical line and time),

- spatial (three spatial components: $\mathrm{x}, \mathrm{y}, \mathrm{z}$ and time),

or with another broken down:

- relative (relative to points located on the tested object),

- absolute (related to fixed points located outside the range of impacts),

- required accuracy of the determined displacement figures of the points examined.

The correct determination of displacements is the basis for determining the direction and speed of changes taking place, as well as the development of safeguards to avoid dangerous events.

The monitoring project should be constructed on the basis of predicted magnitudes and speed of changes taking place, closely related to the staging of mine work. If the changes are slow and related to reaching the appropriate excavation depths or excavation passage through successive sections, it can be assumed that during one measurement cycle there is no change on the tested object larger than the accuracy of the measurement. With this assumption, measurements of the geodetic network covering the tested object and its surroundings can be carried out. The construction of slope monitoring network, absolute (related to fixed points located outside the range of impacts) or relative (referred to points located on the tested object), is crucial to ensure compliance with the accuracy requirements [10]. It should be shaped upon the established type of potential threat, e.g. based on archival data taking account the appropriately tailored measurement methodology, as well as external factors and accuracy of measurement. At the development of the monitoring network consideration should be given to logistic factors, such as access to the site, power availability, etc. The slope monitoring design should be constructed on the basis of projected magnitudes and speed of changes, closely related to the work being phased in during the mine work. If the changes are slow and related to the achievement of appropriate excavation depths - running maintenance requires constant monitoring to avoid disruptions and failures. The literature $[10,11]$ shows how one can monitor deformations based on the use of various geodetic and geotechnical technologies depending on numerous factors, including the required accuracy and frequency of monitoring, etc.

In the case of the slope monitoring, the main purpose of geodetic measurements is to describe geometric changes (e.g. point coordinates)of the surface topography by measuring geometrical elements (e.g. angles, distances or height differences). In the case of typical 
geodetic monitoring, it is necessary to establish a reference geodetic network [11] with fixed control points and several observation points. The control reference points must be outside the expected deformation area. Observation points in which geodetic instruments are set can also be placed directly on a moving slope. Their coordinates must be determined each time before examining the object. Measurements taken from one fixed point to another point are absolute measurements. An alternative to traditional measurement methods has become the 3D laser scanning technique. The advantage over manual data collection techniques is that the laser scanning recording methods allow automated, dense sampling of the object's surface in a short time [12].

\section{Characteristics of the 3D laser scanning method}

The technique of Terrestrial Laser Scanning (TLS) has become a commonly used method of acquiring 3D data. The first commercial systems became available in the 1990s [12]. The laser scanner uses laser light to measure the distance from the sensor to the object in a systematic manner. Most laser scanners are pulse scanners, in which the laser transmitter emits a laser pulse, which, in turn, reflected from the surface returns to the receiver. Based on the flight time, the distance to the reflected surfaces is determined. The measured distances are converted to $3 \mathrm{D}$ coordinates with the information on the origin of the range vector and the scanning angle. In order to convert the measurements into a better, georeferenced spatial coordinate system, the laser measurement must be connected to the GPS device [12]. Many instruments also record the intensity characteristics of the backscattered pulse. As intensities depend on numerous factors, such as surface roughness and reflection of objects, they could be used for visualization and classification purposes. Usually, one scan is not enough to collect data covering the entire object or location, therefore it is required to perform scans from several observation points. Scans from different locations are combined within the same coordinate system in post-processing. In order to ensure a full representation of the terrain surface, the obtained scans should be closely connected with each other and input in the geodetic coordinate system. This is important for the integration of TLS data with other spatial data (e.g. GPS measurements). As a result of data processing, a high resolution digital terrain surface model is obtained that can be exported to many geographic information system (GIS) programs, and used, for example, for modeling and visualization of the measured object. The main advantage of the TLS protocol in comparison with traditional geodesy techniques consists in direct, quick and detailed mapping of the object's geometry in 3D. TLS provides cost reduction and significantly faster data processing. Everything that you see on the stage is captured at the same time, which allows for the comprehensive use of data, both now and in the future [12]. The 3D laser scanning technique allows to record the state of the object or phenomenon independently from the availability of external data, whose spatial and temporal range often limits the observations. At the same time, it maintains high efficiency of measurements resulting from the frequency of sending a light beam (depending on the model, it is from $1 \mathrm{kHz}$ (registration $1000 \mathrm{pts} / \mathrm{sec}$ ) to $1 \mathrm{MHz}$ (approx. 1 million pts $/ \mathrm{sec}$ )). Thanks to the active emission source of the TLS laser beam, it is characterized by the independence of measurements from the lighting conditions and from the transparency of the air. As a result, the efficiency of data acquisition increases. On the basis of the point clouds obtained, a traditional model can be made in the form of an irregular grid of triangles, whose high density allows to generate numerical models with a very realistic appearance (Fig. 2). From generated 3D surfaces, it is possible to extract 2D profiles or contour lines of objects. The obtained models can then be processed and used in GIS and CAD systems for further data integration. The obtained three-dimensional models are made documentation (depending on the user's needs) reflecting the actual state of the object we are interested in 
and giving a graphic image of the planned investments. The digital form of data gives the possibility of constructing environmental models, designing drainage systems, etc.

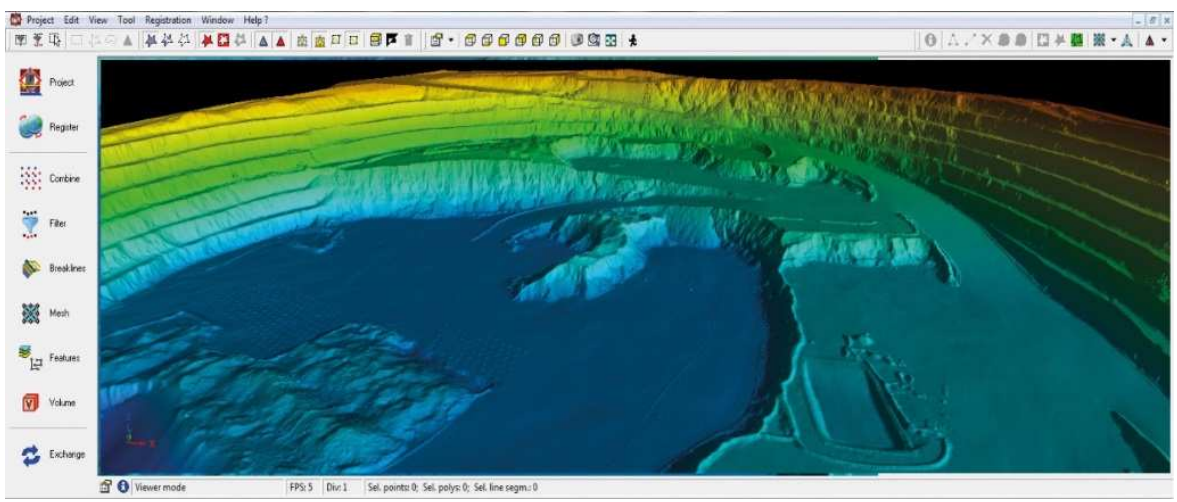

Fig. 2. DTM open pit mine model on the basis of a point cloud [13].

The concept of using terrestrial laser scanning to study deformation processes, which include landslide movements, is based on performing scanning of an area threatened by deformation processes at successive time points, especially during periods of intensification of linear erosion, e.g. after heavy rains or during spring thaws [14, 15]. As a result of superimposing two scans in a local geodetic coordinate system, a differential model is created. An example of such a model is presented in Figures 3 and 4.

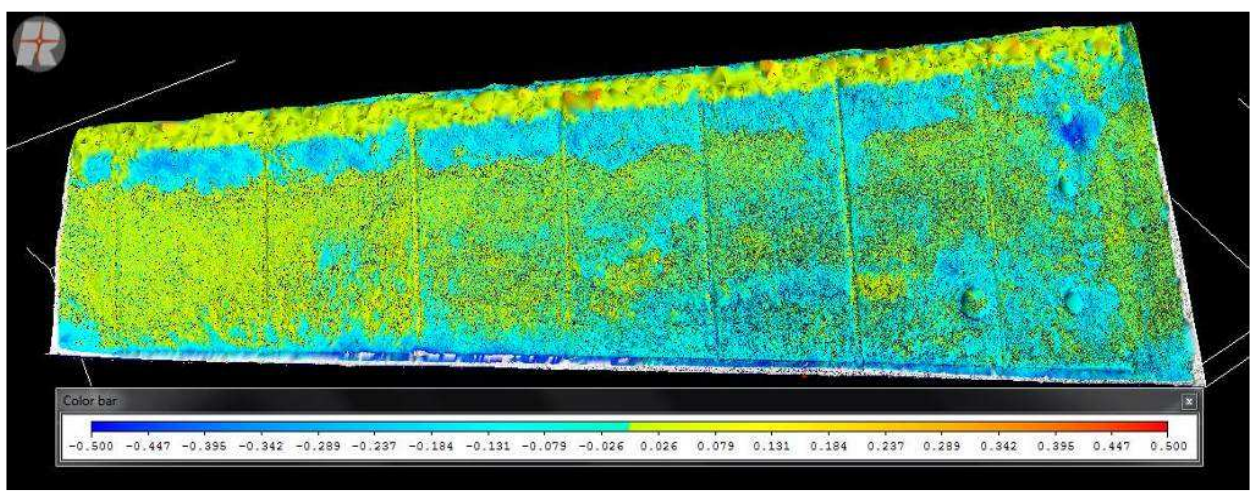

Fig. 3. The differential model of the area threatened by a landslide in Sadowie [16].

To ensure the best results of the tests, models made at particular time points should have the same resolution and accuracy. On the basis of the differential model, it is possible to observe changes in the terrain surface due to landslides [16]. It is possible to almost immediately formulate the prognosis of the development of the phenomenon and to determine the degree of threat. The obtained data in digital form can be used, for example, to simulate dynamic processes [17-20]. The use of 3D terrestrial laser scanning technology to analyze erosive phenomena on the slopes allows us to move away from traditional point measurements using geodetic methods. We are able to evaluate erosive phenomena (both in terms of process intensity as well as events initiating erosion) and also the area coverage of existing processes. The use of TLS involves the need to develop a research methodology, select a scanner, link to a general reference system or the object's own reference system, as well as determine the spatial resolution of the inventory being performed. The consequences of the adopted methodology and technical parameters of scanning affect not only the time and manner of conducting measurements, but also the reliability and accuracy of analyzes. 

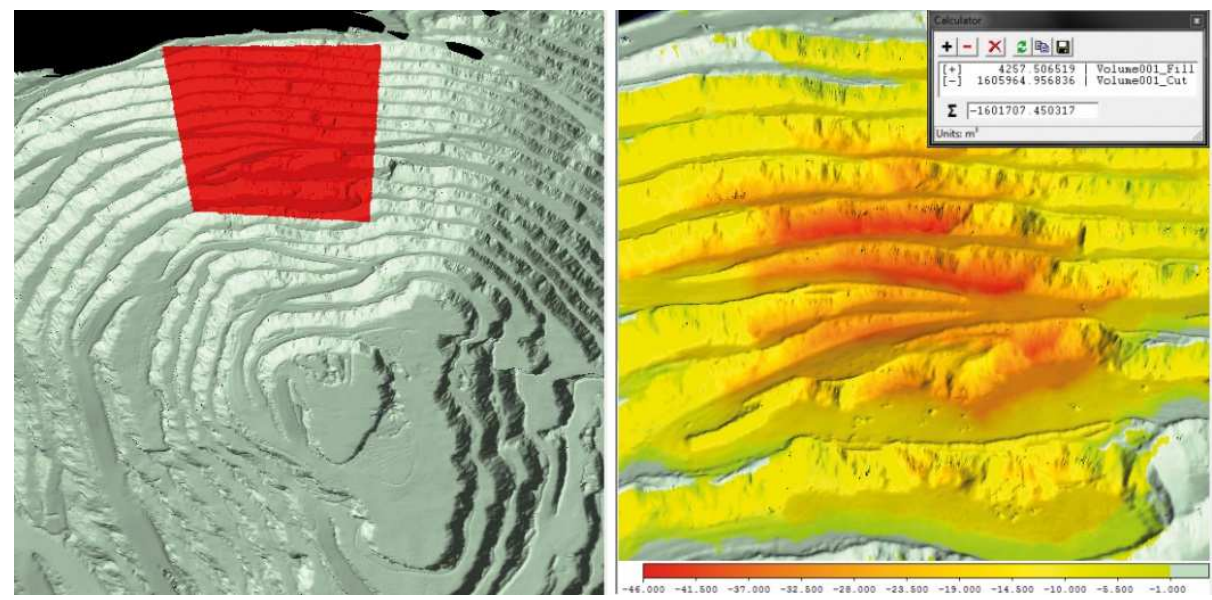

Fig. 4. A differential terrain model for open pit mine with visible surface changes [13].

\section{Examples of using terrestrial laser scanning for slope monitoring in open pit mines}

Terrestrial laser scanning 3D has become a widely used surveying method in the mining site [17-21]. TLS offer many possibilities in the field of terrain deformation monitoring, mainly due to the high spatial resolution and data capture speed, which makes it possible to repeat measurements to collect data in high resolution $[6,18,20]$. Laser scanners work even with reduced visibility caused by e.g. dust, fog, rain, snow, etc., which frequently occur in difficult environments, such as mining sites.

Open pit mines are very often characterized by their large size. They can include areas from 1000 meters to several square kilometers. In mines of such large expanse it is particularly important to prepare and organize the measurements. Usually, survey parameters have to be defined so that the scanning test will set-up properly, considering the mine's depth and range. Figure 5 shows an example of a differential model for the large open pit coal mine in Indonesia. Though large-sized the mine, it is possible to determine changes in the surface area and calculating the volume of rock masses in a relatively short time.

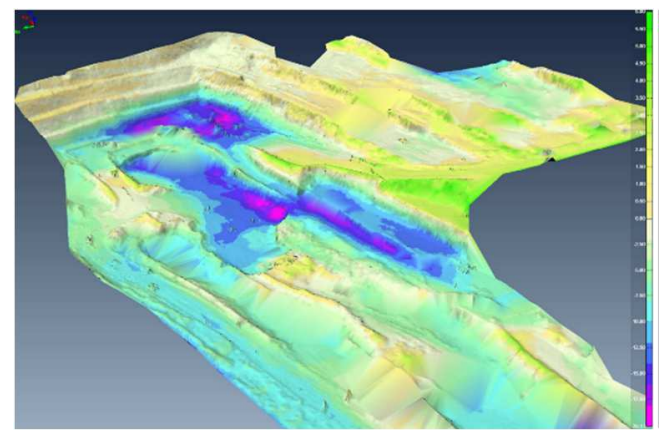

Fig. 5. The differential terrain model of coal open pit mine in Indonesia [22].

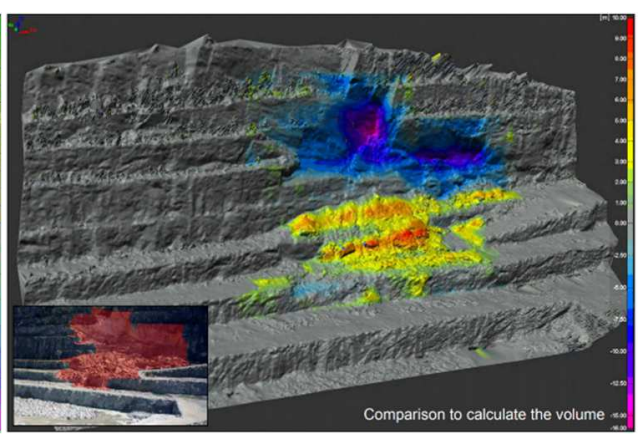

Fig. 6. Color-coded comparison before and after landslide activation [22].

There are examples in the literature of using 3D terrestrial laser scanners to provide information of a potential unstable subsoil detection, assessment of the grading structure performance, which includes identification of slope instabilities and/or evolving failure 
mechanisms [14-26]. Inter alia in platinum mines Mogalakwena and Potgietersrust Platinums Ltd (PPRust) in South Africa the TLS method, along with special software dedicated to open pit mines, is used to monitor pits and slope management $[23,24]$. On the basis of point clouds volume calculations are made and the state of the pit slope is analysed. More importantly, progressive slope movement is calculated and plotted. TLS is used there for long term monitoring of trends and for identifying high risk areas. It provides significant information for determination geohazards and geotechnical risks, as well as is acting as a primary monitoring system providing long-term data to understand the history of the rock masses and its behaviour. The rockfall detection, structural mapping and displacement data aid in highlighting high-risk and hazardous areas. Based on the monitoring data in time, was identified movement locations and rock mass volumes disconnected and accumulated on the top north wall Magalakwena mine. The events analysis over time allowed to divided the mine area into zones from the risk exposure.

In Brazil gold mine, 3D laser scanners were used to analyse a landslide to calculating the volume of the material loss (Fig. 6). The volume was calculated for about 8,350 cubic meters in the upper part of the rock face [22]. To capture the entire extension, $1.5 \mathrm{~km}$ by $1 \mathrm{~km}$, with a depth of about $700 \mathrm{~m}$, the mine was scanned from six positions, the coordinates of which were determined using a GPS receiver mounted on the top of the scanner. Accuracy was obtained at cm-level.

In Italian white marble open pit mine "Botticino", located in north Italy, a combination of digital photogrammetry by UAV and TLS was proposed. This resulted in an increase in local accuracy up to $+/-2 \mathrm{~cm}$ [25].In Poland, research is being carried out on the use of the 3D laser scanning method in the "Bełchatów" Brown Coal Mine [6, 26].

\section{Conclusions}

The laser scanning method becomes a competitive method for classical and photogrammetric measurements methods of slope monitoring in terms of accuracy. It is excellent for objects with a fan-shaped construction, which include open pit mines. The advantages and limitations of this method in the context of slope monitoring are shown in Table 1.

Table 1. Advantages and limitations of laser scanning in relation to conventional methods

\begin{tabular}{|l|l|}
\hline \multicolumn{1}{|c|}{ Advantages } & \multicolumn{1}{|c|}{ Limitations } \\
\hline $\begin{array}{l}\text { Capturing a large coverage of a rock } \\
\text { surface with high resolution }\end{array}$ & $\begin{array}{l}\text { Difficult to monitor small deformations, } \\
\text { below few mm }\end{array}$ \\
\hline $\begin{array}{l}\text { A short time of capturing (a few minutes } \\
\text { depending on the resolution selection) }\end{array}$ & $\begin{array}{l}\text { Range of the laser scanner is limited by rock } \\
\text { mass reflectivity. Maximum range } \\
\text { decreases if the reflecting surface is wet. }\end{array}$ \\
\hline $\begin{array}{l}\text { All the data are digital and in 3D, both } \\
\text { image and co-ordinates }\end{array}$ & \\
\hline $\begin{array}{l}\text { After reference surveying, all scanning data } \\
\text { are registered in a global co-ordinate } \\
\text { system, and the rock mass is referenced to } \\
\text { its real position in space }\end{array}$ & \\
\hline $\begin{array}{l}\text { Possibility to determine geometrical } \\
\text { features, e.g. length between points, } \\
\text { orientation of a fracture, etc. }\end{array}$ & \\
\hline $\begin{array}{l}\text { Visual information, e.g. 2D and 3D digital } \\
\text { image, 3D virtual model. }\end{array}$ & \\
\hline
\end{tabular}




\section{Possibility to determine physical changes, e.g. the movement of rock masses, water leakage identification and different rock type identification by different reflective intensity}

Terrestrial laser scanning provides very fast and easy access to data in real time. Nevertheless, terrestrial laser scanning should not be treated as the only measurement method and should be supplemented with more accurate geodetic measurements, established by engineering practice.

\section{References}

1. P. Dobak, A. Drągowski, Z. Frankowski, A. Frolik, R. Kaczyński, A. Kotyrba, J. Pinińska, S. Rybicki, H. Woźniak., Zasady dokumentowania warunków geologicznoinżynierskich dla celów likwidacji kopalń [The principles for documenting geological and engineering conditions for the purposes of mine closure], Ministerstwo Srodowiska, ISBN 978-83-60117-86-6 Warszawa (2009)

2. M. Krawczyk, Stan bezpieczeństwa w odkrywkowych zakładach górniczych oraz zmiany w przepisach obowiazujacych przy eksploatacji kopalin metoda odkrywkowa [The state of safety in open pit mining and changes in the regulations applicable to the exploitation of mineral resources opencast method] Proc.Conf. Mining Workshop, 49-63; http://warsztatygornicze.pl/wp-content/uploads/2007_4.pdf (2007)

3. http://zzprckwb.org.pl/news/800

4. D. Milkowski, J. Nowak, Zabezpieczenie i monitoring zagrożenia osuwiskowego na filarze rzeki Nysa Łużycka oraz osuwiska "Świniec", [Protection and monitoring of landslide hazard on the Nysa Łużycka river and "Świniec" landslide], Bezpieczeństwo Pracy i Ochrona Środowiska w Górnictwie 6, 14-21 (2009)

5. D. Milkowski, A. Górecka, M. Wójcicka-Milewska, Zabezpieczenie $i$ monitoring osuwisk powstatych na zboczu pótnocnym wyrobiska odkrywkowego BOT KWB TURÓW $S A$., [Protection and monitoring of landslides formed on the northern slope of the BOT KWB TURÓW SA open pit work], Górnictwo i Geoinżynieria 32 (2) 247-256 (2008)

6. J. Maciaszek, P. Ćwiąkała, Badania możliwości zastosowania skanowania laserowego do monitoringu osuwisk zboczy wyrobisk odkrywkowych na przykładzie KWB „Betchatów” [Research on the possibilities of laser scanning method using for landslides monitoring on slopes in open pit mine, on the example of KWB "Betchatów"] Przegląd Górniczy 66 (6) 52-57 (2010)

7. https://www.nj24.pl/article/gigantyczne-osuwisko-w-kopalni-turow

8. A. Mirek, L. Biały, Stan zagrożeń naturalnych $w$ kopalniach węgla brunatnego ze szczególnym uwzględnieniem zagrożeń występujących w KWB „Betchatów” [The state of natural hazards in brown coal mines, with particular emphasis on hazards occurring in KWB "Betchatów"], Górnictwo i Geoinżynieria 33 (2) 327-341 (2009)

9. H. Bryś, S. Przewłocki, Geodezyjne metody pomiarów przemieszczeń budowli [Geodetic methods of measurements of building displacements]), Wydawnictwo Naukowe PWN SA, Warszawa (1998)

10. M. A., R. Cooper, Control Surveys in Civil Engineering, William Collins Sons \& Co. Ltd., London (1987) 
11. W. Welsch, O. Heunecke, H. Kuhlmann, Auswertung geodätischer Überwachungsmessun-gen [Evaluation of geodetic monitoring measurements], In: Möser et al. (edts.): Handbuch Ingenieurgeodäsie. Wichmann Verlag, Heidelberg, (2000)

12. N. Pfeifer, C. Briese, Laser Scanning - Principles and Applications, Austria (2007)

13. http://www.riegl.co.at/media-events/newsletter-archiv/0512-rimonitor-and-rimining/

14. J. Gance, J.P. Malet, T. Dewez, J. Travelletti, Eng. Geol. 172, 26-40, (2014) doi: 10.1016/j.enggeo.2014.01.003J.

15. Travelletti, J.P. Malet, Eng. Geo. 128, 30-48, doi: 10.1016/j.enggeo.2011.05.003

16. E. Pilecka, M. Bazarnik, Application of terrestrial laser scanner for monitoring the railway infrastructure threatened by landslides, Monographie - recent Advances in civil Enginearing: Structural Mechanics edit. Stypuła K., 171-190, (2015) Wydawnictwo PK, ISSN 0860-097X

17. E. Pilecka, D. Szwarkowski, E3S Web Conf. 24, 01006, (2017) doi : 10.1051/e3sconf/20172401006

18. M. Bazarnik, Bulletin of the Mineral and Energy Economy Research Institute of the Polish Academy of Sciences 94, 149-160 (2016)

19. E. Pilecka, D. Szwarkowski, Budownictwo Górnicze i Tunelowe 4, 21 (2015) (in Polish)

20. Z. Muszyński, W. Milczarek, Modelowanie przemieszczeń pionowych na podstawie danych z naziemnego skanera laserowego [Modeling of vertical displacements based on data from terrestrial laser scanner], Geoinformacja jako metoda ochrony przed geozagrożeniami, Warszawa, 42-63 (2014)

21. V. Kajzar, R. Kukutsch, N. Heroldová, Acta Geodyn. Geomater. 12/1 (177), 51-58, (2015) doi: 10.13168/AGG.2015.0004

22. D. Conforti, Using Static and Mobile Laser Scanners to Measure and Manage Open Pit Mines, Australian Institute of Mine Surveyors Conference 11 -13 August 2010 http://www.minesurveyors.com.au/files/members/2010Convention/Papers/Dario\%20C onforti\%20-\%20Optech/Da rioConforti-FinalPaper.pdf

23. M. Radzilani, 3D Laser Mapping, Position IT, EE Publisher (2015) http://www.ee.co.za/article/slope-monitoring-solution-open-pit-mines.html

24. M. J. Little, Slope monitoring strategy at PPRust open pit operation, The South African Institute of Mining and Metallurgy International Symposium on Stability of Rock Slopes in Open Pit Mining and Civil Engineering, 211-230, (2006)

25. G. Vassena, A. Clerici, Open pit mine 3D mapping by TLS and digital photogrammetry: $3 D$ model update thanks to a slam based approach, The International Archives of the Photogrammetry, Remote Sensing and Spatial Information SciencesXLII-2, 1145-1148 (2018) doi : 10.5194/isprs-archives-XLII-2-1145-2018

26. J. Wajs, Mining Science 22, 75-83, (2015) doi :10.5277/msc152207 